\title{
MILITARY LAW PRACTITIONERS AND \\ ACADEMIC DISCOURSE: A SINE QUA NON FOR DEVELOPING MILITARY LAW
}

\author{
Michelle Nel \\ Stellenbosch University
}

\begin{abstract}
There has been limited development in South African military law since the inception of the Union Defence Force in 1912. Military law has mainly evolved as a way to enforce discipline in a force consisting of mostly conscripted members, and a historical comparison of the relevant legislation shows no renewal in military justice or its processes in spite of a shift to a new all-volunteer force. Surely, the approach towards discipline and military justice should also have changed. However, the limited development seen since was only brought about when necessitated by constitutional challenges and external factors. This also seems to be true for the military law practitioners' understanding of what military law entails. Generally, military law is understood as the criminal law of the soldier, limiting it to the realm of military justice. Considering the expanding role of armed forces internationally, and the secondary roles of their employment, there is a clear need for a broadening of the definition and scope of military law as a discipline. The author argues that there are a number of other disciplines that could be of great assistance in a broadening of our understanding of military law. This article therefore argues that there is a critical need to develop military law as well as our understanding of what it entails. This requires the development of a legal-academic discourse within the discipline.
\end{abstract}

\section{Introduction}

Scientia Militaria, South African Journal of Military Studies, Vol 45, No. 2, 2017, pp. 1-19. doi : $10.5787 / 45-2-1212$
Although a general definition of what constitutes 'the law' may not be easy to pinpoint, it is explained in every introductory 
law course in generally similar terms. ${ }^{1}$ Hand in hand with this definition is the demarcation of the various disciplines of law. Most disciplines are easily identifiable and their sources clearly outlined. Some disciplines have been with us since the inception of South African law, while others, such as Constitutional Law and Internet Law, are relatively new additions. The law does not remain stagnant, and as societies and the legal landscape change and develop, new areas of the law develop and require academic discourse. Textbooks, legal research and case law on most disciplines abound. South African Military law is not a new discipline. It has been in existence since the inception of the armed forces; yet, it is a legal discipline that is relatively unknown.

There are no South African textbooks available on South African Military Law. There are only a limited number of academics doing research and publishing in this area, ${ }^{2}$ and in spite of the influence of the Constitution on military law, the content of the subject matter has remained relatively stagnant. ${ }^{3}$ There has been only limited development since the inception of the Union Defence Force in 1912. Offences, punishments and procedural aspects where copied from the 1881 British Army Act, remained unchanged until the promulgation of the 1957 Defence Act, ${ }^{4}$ which consolidated the discipline codes of the various Arms of Service into a uniform Military Discipline Code,,$^{5}$ the same one still in use in 2016 . The advent of the Constitution necessitated some changes to the military justice system, but said

\footnotetext{
${ }^{1}$ See for example Kleyn, D \& Viljoen, F Beginner's Guide for Law Students (Juta Law 2010) at 1 and Maisel, P \& Greenbaum, L Introduction to Law and Legal Skills (LexisNexis 2001) at 15.

${ }^{2}$ Published articles are few and far between. Historically there are no prolific publications on the subject matter. Authors who have published one or two articles include CJ Pretorius (1973), ELK de Villiers (1974), MM Oosthuizen (1990), H van der Westhuizen (1994), R Adm D Smart (1994), Prof. L Heinecken and M Nel (2003), Prof. M Carnelley (2005) and more recently Prof. EA Tshivhase. Available research is limited to the question surrounding constitutional concerns regarding the appointment and independence of the military judges.

${ }^{3}$ The South African Law Reform Commission has had some discussion and suggestions in 2011 regarding changes they regard as necessary, but to date there has been no forward momentum regarding their recommendations - see South African Law Reform Commission 'Discussion Paper 123: Statutory Law Revision: Legislation Administered by the Department of Defence, Project 25' (2011), available at http://www.justice .gov.za/salcr/spapers/dp123.pdf. It is also foreseen that the proposed Military Discipline Bill will result in considerable changes to the military justice system, although there is no clear indication when the Bill will serve before the National Assembly. The last official notice in this regard was in GN 650 of 2008, published in GG 31078 of 23 May 2008, which indicated that the Minister of Defence intended to introduce the Bill in June 2008.

${ }^{4}$ Defence Act 44 of 1957.

${ }^{5}$ Schedule 1 of the Defence Act 44 of 1957.
} 
changes are largely limited to procedural aspects and seemingly cannot be attributed to any internal drive for change and development from within the Legal Services Division or research within the field.

Change was brought about by pressure outside the South African National Defence Force (SANDF), by court cases compelling change and the enforcement of a number of human rights. The most pivotal case was arguably the 1999 case of Freedom of Expression Institute $v$ President, Ordinary Court Martial, ${ }^{6}$ which specifically found that the ordinary court martial format in use did not conform to the constitutional understanding of what constitutes an 'ordinary court' in terms of section 35(3)(c) of the Constitution, forcing the swift implementation of the Military Discipline Supplementary Measures Act (MDSMA). ${ }^{7}$ This in turn paved the way for the change to the current Court of a Military Judge format. The main aims of the MDSMA were to replace the unfair and unconstitutional practices in the military courts with a constitutional military court system, independent judges, the right to appeal and review as well as providing recourse to the High Court of South Africa. ${ }^{8}$ As mentioned, these changes only addressed procedural aspects of the military justice system. It is however this researcher's contention that military law encompasses much more than merely military justice.

\section{Military legal scholarship}

The unrealised expectation of a seismic shift in our approach to military law created by the movement from a conscription force in an unconstitutional era to an all-volunteer force in a constitutional human rights and international law environment is questionable. ${ }^{9}$ Although military law only affects a small percentage of our population directly, its potential influence should not be underestimated. The SANDF is playing a prominent role in the international peacekeeping environment, especially at regional and continental level. Conduct by members of the SANDF as well as policy decisions may have diplomatic consequences and are brought to the

\footnotetext{
${ }^{6}$ Freedom of Expression Institute v President, Ordinary Court Martial 1999 (2) SA 471 (C).

${ }^{7}$ Military Discipline Supplementary Measures Act 16 of 1999.

${ }^{8} \mathrm{Nel}, \mathrm{M}$ Sentencing Practice in Military Courts (unpublished LLD thesis, Unisa 2012) at 16.

${ }^{9}$ With the advent of the Constitution, the security sector, including the armed forces, went through extensive changes. Africa, S 'The Transformation of the South African Security Sector: Lessons and Challenges' (2011) DECAF Policy Paper no 33 at 1 lists a number of changes as a new constitutional and legislative framework, integration of the statutory and non-statutory forces, the establishment of a common culture among the various security forces, policy reviews and the introduction of a human rights approach.
} 
attention of civilian South Africa more and more frequently. ${ }^{10}$ Taxpayers demand results, and an effective military law system could go a long way towards prevention and cure where ethical, trusted legal advice is available.

Without research and development, a discipline stagnates and can arguably no longer be effective. ${ }^{11}$ Development relies on research and legal scholarship and influences all areas of the law. It affects "judicial decisions, legislative policies, administrative practices, and cultural attitudes". ${ }^{12}$ The ability of a discipline to develop by means of research would assume that it is an academic discipline, which raises the question whether military law could in fact be regarded as such. To be regarded as an academic discipline -

- $\quad$ military law must collect the knowledge in a system, i.e. describe and explain information in an existing framework;

- $\quad$ the knowledge must be obtained by means of an academically recognised method; and

- $\quad$ the aim must be to collect international knowledge. ${ }^{13}$

The discussion below will attempt to address some of these aspects.

There are a number of ways in which research can be done, depending on the researcher's motivation. In the traditional descriptive manner, one would study legislation and case law and the way it can be applied in the specific legal discipline. ${ }^{14}$ This approach regards law as a practical discipline since the results will be valuable to legal practitioners in understanding and applying legal rules. ${ }^{15}$ In general, a comparative study would also yield fruitful results, especially with the aim of developing a discipline. A third possibility would be studying the law as part of the humanities. ${ }^{16}$ Here I argue that legal academics and military law practitioners should be open toward other fields within the humanities, especially when developing military law into an international discipline instead of a very narrow

\footnotetext{
${ }^{10}$ A number of recent incidents come to mind, such as the 13 soldiers who died on deployments in March 2014 in the Central African Republic, recent complaints of sexual misconduct by South African soldiers on deployment with the UN as well as questions raised about the continued efficacy of Op Copper in a number of Defence Web discussions.

${ }^{11}$ Kamba, WJ 'Comparative Law: A Theoretical Framework' (1974) 23 International and Comparative Law Quarterly at 494 argues that legal education is "incomplete without legal research".

${ }^{12}$ Rhode, DL 'Legal Scholarship' (2002) 115 (5) Harvard Law Review at 1328.

${ }^{13}$ Smits JM The Mind and Method of the Legal Academic (Edward Elgar 2012) at 37-8.

${ }^{14}$ Ibid 1.

${ }^{15}$ Siems, MM \& Sithigh, DM 'Mapping Legal Research' (2012) 71 (3) Cambridge Law

${ }^{16}$ Ibid 654. Journal at 652 .
} 
branch of our domestic law. ${ }^{17}$ Law may also be studied as part of the social sciences ${ }^{18}$ where one would investigate the consequences of applying certain legal rules, determining the effect of law on society. ${ }^{19}$ It is submitted that the military law environment does not lend itself easily to empirical research in determining the effect of military law on society. Even if one would follow the empirical route, this type of research is hampered by challenges such as difficulty in accessing research participants within the SANDF and the classification of information. ${ }^{20}$ The present discussion will consequently focus on the role of research as a practical, descriptive discipline in the development of military law and brief mention will be made of the role of comparative studies and the humanities.

\section{Traditional descriptive research}

Descriptive legal research denotes a systematic description of the law in a certain field, ${ }^{21}$ in this instance of military law, and it remains the most common way in which legal research is done. One cannot do away with a proper description of the legal discipline. At a basic level, this would include a neutral description of what military law is, and it explains to the reader how it operates. This is what is typically found in legal textbooks. This would include an analysis of the relevant legislation and case law, placing it in a system and then developing this system further. ${ }^{22}$ Such a system is set out as a "coherent set of concepts, rules and principles" which is done "by exposing contradictions, defining concepts and classifying rules and cases". ${ }^{23}$ Existing materials are produced by the legislature and the courts, it is described to make it easier for others to understand, consequently making the outcome more predictable $^{24}$ thereby creating our legal doctrine. ${ }^{25}$

\footnotetext{
${ }^{17}$ See in this regard Smits op cit 1.

${ }^{18}$ Siems \& Sithigh op cit 655.

${ }^{19}$ Smits op cit 9.

${ }^{20}$ For a discussion on the difficulties encountered when doing military research, see Heinecken, L 'Reflections on Insider-outsider Experiences of Military Research in South Africa' in Carreiras, H, Castro, C \& Frederic, S (eds) Research in Military (Routledge 2016) at 41.

${ }^{21}$ Smits op cit 11 .

${ }^{22}$ Ibid 12-3.

${ }^{23} \mathrm{Ibid} 15$. One is not able to describe the law without also interpreting the law - see the discussion in Van Hoecke, $M$ \& Warrington, $M$ 'Legal Cultures, Legal Paradigms and Legal Doctrine: Towards a New Model for Comparative Law' (1998) 47 International and Comparative Law Quarterly at 523-4.

${ }^{24}$ Smits op cit 16.

${ }^{25}$ Tiller, EH \& Cross, FB 'What is Legal Doctrine?' (2006) 100 (1) Northwestern University Law Review at 517.
} 
The problem is that once a legal system is put in place, that system will generally determine the outcome of future descriptions of the subject matter. Even if new rules are developed, legal practitioners will fit it into existing groupings. This in turn influences the practice and application of military law since legal academics work normatively on a system used in practice. Any proposed developments and changes to the system will have to fit into the existing system. ${ }^{26}$ The research is not separated from practice. Although the legislature and the courts can in effect create law, the unwillingness to move outside the existing groupings could prove problematic for any proposed expansion of the existing understanding and application of military law.

Military law has been in existence in some form since the beginning of military history, and in South Africa, since the inception of our armed forces. ${ }^{27}$ This is a discipline seemingly resistant to change. Luban' ${ }^{28}$ quote of Quine seems apt under the circumstances: "We are like sailors who on the open sea must reconstruct their ship but are never able to start afresh from the bottom."

All military legal practitioners are conversant with the descriptive method of research - it is the prevalent method commonly used in law faculties throughout South Africa. Even though it has the potential to influence military law, and is potentially valuable to judges, practitioners and policymakers, ${ }^{29}$ descriptive research in the military context faces a number of challenges.

There are several statutes applicable to the military law environment. The most important being the South African Constitution. As the supreme law, all other statutes are subject to the Constitution. This means that all statutes must comply with the imperatives of the Constitution, including the human rights contained therein. ${ }^{30}$ This places a burden on the Military Courts to interpret and apply these Constitutional imperatives. ${ }^{31}$ Compliance will go a long way towards the ethical, trusted military legal system alluded to earlier.

The military justice system is a creature of statute and it cannot exist without the legislation that created it. There are three statutes that find particular application in military law: the Defence Act, ${ }^{32}$ the Military Discipline Supplementary Measures

\footnotetext{
${ }^{26}$ Smits op cit $17-8$.

${ }^{27}$ For an overview of the history of military, see Nel op cit 36-126.

${ }^{28}$ See Luban, D 'Military Necessity and the Cultures of Military Law' (2013) 26 Leiden Journal of International Law at 349.

${ }^{29}$ Rhode op cit 1339.

${ }^{30} \mathrm{~S} 2$ of the 1996 South African Constitution.

${ }^{31} \mathrm{~S}$ 39(1) of the Constitution.

${ }^{32}$ Defence Act 42 of 2002.
} 
Act (MDSMA) ${ }^{33}$ and the Military Discipline Code (MDC). ${ }^{34}$ Although the Defence Act and the MDSMA have been written after the advent of the Constitution and should comply with the Constitutional demands, ${ }^{35}$ the MDC stems from 1957, with no discernible changes from the 1912 MDC. It is foreseen that the proposed Military Discipline Bill will bring about a number of changes and hopefully effect the longawaited constitutionalisation of the Military Discipline Code. ${ }^{36}$ Since the Bill is not available for perusal, it is unclear to what extent, if any, this Bill will influence the existing Military Law legislation, and this situation is not conducive towards research or much needed development of military law. ${ }^{37}$ It is of concern that the Military Discipline Bill has been pending since at least 2005. Continued assessment and review of legislation is important in order to identify problems within the military justice system and to recommend improvements, as well as to identify critical needs. ${ }^{38}$ Since the law can be regarded as both legal and political, ${ }^{39}$ research and development become necessary to adapt to the changing "legal and political context". ${ }^{40}$ With legislation taking more than a decade to see the light of day, the changes to the "legal and political context" will pass us by.

In general, one only finds limited descriptive research published in military law. This is by no means an indication that research in the field is not being done at all. A large part of the legal services rendered to the SANDF includes the writing of official legal advice papers on a wide selection of topics and legal questions. The problem is that these papers are not made available for publication or even at a more restricted level, to the military legal practitioners specifically. Although there are a number of classified situations which understandably would prevent publication, it is surely possible to publish those legal opinions that are not regarded as classified. ${ }^{41}$

${ }^{33}$ Military Discipline Supplementary Measures Act 16 of 1999.

${ }^{34}$ First Schedule to the Defence Act 44 of 1957.

${ }^{35}$ This is however not the case. There are still serious constitutional concerns regarding aspects such as the difference in treatments between the ranks, the validity of certain offences and concerns regarding sentencing and yet little has been done in terms of academic critique of these voids and concerns.

${ }^{36}$ To what extent the MDC will be changed is unclear, as no copy of the draft Bill is available. It is expected, however, that the biggest changes will be to the jurisdiction of Commanding Officers to exercise discipline over their subordinates.

${ }^{37}$ As there is no indication when the Bill will be promulgated as a law, this situation can continue indefinitely.

${ }^{38}$ Vashakmadze, M 'Understanding Military Justice' (Geneva Centre for the Democratic Control of Armed Forces 2010), available at http://www.dcaf.ch/Publications/Publication-Detail?Ing=en\&id=127045 at 18.

${ }^{39}$ Tiller \& Cross op cit 528.

${ }^{40}$ Vashalmadze op cit 18.

${ }^{41}$ Many topics are regarded as sensitive or controversial by the SANDF and are classified accordingly. Research on relevant issues should be published, but military researchers 
It should even be possible to generalise classified information by, for example restating the question in more generic terms, and then making it available. This would be an invaluable tool in the development and education of military legal practitioners as well as providing a body of research with which to develop military law.

The South African legal system is based on a system of precedent where courts are bound by their judgments in previous cases,${ }^{42}$ and herein lies the greatest strength of legal doctrine - the ability of the higher court to influence the decisions by the lower court. ${ }^{43}$ The legal doctrine therefore operates in a hierarchical structure with the lower courts using the doctrine to resolve the case with which they are busy. They find guidance from the precedents and decisions of the higher courts. ${ }^{44}$ The military legal system is no different. Although one Court of a Military Judge (CMJ) is not bound by the decision of another CMJ, it is bound by the decision of the Court of Military Appeal (CMA). The role of the higher court (the CMA) in the hierarchy is to consider the wider effect of their decisions on the lower courts and as such, the CMA must carefully consider its decisions and application of doctrine. ${ }^{45} \mathrm{CMA}$ decisions are made available within the legal services division, but they are not published in any official format nor indexed, making research on CMA decisions laborious. Since these decisions are only distributed internally, civilian researchers do not have access, further hampering research in the area. Earlier decisions by the CMA did not include any reasons for their judgements, and more recent cases do not always contain extensive legal discussions on their reasons for judgement, making it difficult for the lower courts to consider the military legal doctrine.

Only a limited number of CMJ cases are subjected to appeal or review by the CMA. ${ }^{46}$ Since only CMA decisions are made available, the bulk of all CMJ decisions are never reported and distributed. Consequently a vast body of military case law is not available for research. It is therefore conceivable that a number of potential important decisions, which are not reviewed by the CMA, are never made

have found that controversial or critical findings have resulted in them being unable to publish their research due to restrictions placed on their findings. See in this regard Heinecken op cit 43.

${ }^{42}$ Kleyn \& Viljoen op cit 58.

${ }^{43}$ Tiller \& Cross op cit 526.

${ }^{44}$ Ibid 531.

${ }^{45}$ Ibid.

${ }^{46}$ In terms of Rule 71(1) MDSMA and s 34(6) MDSMA CMJ proceedings are forwarded to the CMA on automatic review where an accused is sentenced to imprisonment (including suspended imprisonment), cashiering, discharge with ignominy or dismissal or discharge from the SANDF. In terms of s 34(5) MDSMA the accused may also apply for a review of their case by the CMA. 
available to military legal practitioners, thereby impoverishing military law. The importance of judicial decisions in legal research must be highlighted. It has been argued that "the language of judicial opinion represents the law" and "a decision to ignore [judicial] opinions misses the law". ${ }^{47}$ Since all CMJ decisions are recorded and transcribed it should be feasible to publish them in a format similar to the various law reports already available in South Africa.

\section{A comparative method of research}

Descriptive legal studies form the basis for comparative research in that it use the legal systems described and systemised by the descriptive method. ${ }^{48}$ Comparative research describes the law by comparing one's own legal system with that of a foreign jurisdiction. Generally, it is directed at comparing "similar legal systems within the same legal family". ${ }^{49}$ The South African Constitution in fact requires comparative application of the law. ${ }^{50}$

There are a number of reasons to use a comparative method of research. ${ }^{51}$ Comparing one's own system with foreign systems tends to open up possibilities, taking practitioners out of self-imposed legal isolation. ${ }^{52}$ Isolation and a narrow application of the law may in fact be detrimental to the development of the legal system - a state of affairs directly in contradiction to what is advocated in this article. It is by comparison that one learns to question the rules, solutions and norms within one's own system, ${ }^{53}$ thereby stimulating development.

When one once again considers the historic development of military law, it is clear that a number of military judicial systems developed from a common denominator - the British system, and in spite of domestic influences, these systems have largely retained their roots. ${ }^{54}$ This should create fertile ground for comparison.

\footnotetext{
${ }^{47}$ Tiller \& Cross op cit 518, 523.

${ }^{48}$ Van Hoecke \& Warrington op cit 530.

${ }^{49}$ Smits op cit 25-6. See also Reitz, JC 'How to do Comparative Law' (1998) 46 (4) The American Journal of Comparative Law at 618-9 and Kamba op cit 486.

${ }^{50} \mathrm{~S} 39(1)$, which compels any court or tribunal to consider international law and allows the consideration of foreign law.

${ }^{51}$ Kamba op cit 490 includes academic studies, legislation and law reform, the judicial process, unification and harmonisation, international law and international understanding

${ }^{52}$ Ibid 492. among the reasons for comparative research.

${ }^{53}$ Ibid.

${ }^{54}$ Fidell, ER 'A World-wide Perspective on Change in Military Justice' (2000) 48 The Air Force Law Review at 206 states that "[i]n spite of the difficulty of establishing its etiology, however, the existence and vast extent of this common core of legal systems cannot be doubted".
} 
The international nature of military operations is potentially ideally suited for this type of research. ${ }^{55}$

Since approximately 2000, there have been a number of developments in military law at international level. ${ }^{56}$ The reasons for the developments differ from country to country, ranging from the need to adapt to human rights developments within their jurisdictions to an improvement of the effectiveness of the military justice system and the re-organisation of the armed forces in post-conflict situations. ${ }^{57}$ Since the motivation for change will focus the research in a particular military justice system, the benefit gained by studying that system might unfortunately be limited. Comparative legal research requires a common point of departure in order to make a comparison. ${ }^{58}$

The current international focus relates to terrorism, jurisdiction over civilians and the treatment of juveniles. These are not challenges faced by South Africa. The use of contemporary literature on military law from these jurisdictions would consequently not be of significant assistance. Comparative studies with Canada and Australia have however proved beneficial in the context of research on the shared concerns regarding the independence of military judges. ${ }^{59}$ Comparative study is consequently limited in the area of military justice but may prove useful in the areas of operational and international law due to the international utilisation of the armed forces. This is possible when considering that one of the valuable functions of comparative studies listed by Kamba ${ }^{60}$ refers to the neutralisation of tensions and the promotion of international understanding, thereby facilitating peaceful relations. This is possible due to the transnational nature of comparative studies, which leads to a better understanding of the legal traditions and institutions of other countries. A military legal practitioner armed with this knowledge will be invaluable to a commander in the field.

\footnotetext{
${ }^{55}$ Fidell (ibid 202) gives three reasons for international collaboration as (1) the need to apply foreign law in domestic courts; (2) the ability to borrow beneficial ideas and (3) the enhancement of cross-border cooperation. See also Cotterrell, R Law, Culture and Society: Legal Ideas in the Mirror of Social Theory (Ashgate 2006) at 130, who lists a number of further reasons, with providing "legal solutions to causes of international conflicts and so promote international understanding" being relevant in this context.

${ }^{56}$ Fidell op cit 195.

${ }^{57}$ Vashakmadze op cit 10 and Dahl, AW 'International Trends in Military Justice', paper presented at the SJA/LOS Conference in Garmisch-Partenkirchen (2008), available at http://www.ismllw.org/PDF/2008-01-

${ }^{58}$ Reitz op cit 622. International\%20Trends\%20in\%20Military\%20Justice-UK.pdf.

${ }^{59}$ See in this regard the research done by Prof. AE Tshivhase from the Faculty of Law, NMMU.

${ }^{60}$ Kamba op cit 490 and discussed at 504-5.
} 
Comparative research is critical in identifying areas requiring law reform, especially in the form of new legislation, but one should remember that any adoption of foreign law would be modified to reflect the unique characteristics of South African law, specifically in terms of the Constitution. ${ }^{61}$ Legislation remains the most effective way to create, change or improve the law. ${ }^{62}$

\section{The law as part of the humanities}

An approach of research of law as part of the humanities aims towards the understanding of the law. ${ }^{63}$ Although we still tend to see legal research as practical descriptive research, I would argue that in accepting an expanded definition of military law, considering other disciplines, both inside and outside the legal environment becomes necessary - hence, the need for legal research as part of the humanities. ${ }^{64}$

This is underscored by the practice of military law in a military environment. What does the SANDF do? The SANDF is, amongst others, involved in human security issues. Therefore, military law must include this. One of the roles of the military legal services is to advise the SANDF and as such it should be conversant with, for example, security governance. This would require military legal practitioners with the necessary skills and knowledge of the security environment, including human security, to provide ethical advice that could inform policy and doctrine.

In the operational domain, military strategy as a discipline can be of invaluable assistance. It has been argued that due to the changing character of conflict, new directions in legal studies and debates regarding interventions have resulted in a disintegration of the barriers between strategy and law. ${ }^{65}$

${ }^{61}$ Reitz op cit 624-5 and Kamba op cit 495. See in this regard also $S v$ Makwanyane 1995 (3) SA 391 (CC) regarding the limitation in using foreign law in the South African context.

${ }^{62}$ Kamba op cit 496.

${ }^{63}$ Siems \& Sithigh op cit 655 . As such comparative research also forms part of the humanities - see in this regard Reitz op cit 625.

${ }^{64}$ Considering other field of study or disciplines remains a comparative method of research see Reitz op cit 627.

${ }^{65}$ Smith, TW 'The New Law of War: Legitimizing Hi-tech and Infrastructural Violence' (2002) 46 (3) International Studies Quarterly at 355 and 365, where he refers to the "marriage of [these two] disciplines". 


\section{Expanding the definition and understanding of military law}

The diversity and influence of the various disciplines are critical in understanding the concept 'military law', and one of the first steps in understanding a subject and where it fits in is developing an acceptable definition of that subject. It is in fact challenging to find an acceptable existing definition of the concept 'military law'. An overview of the development of military law through the ages crystallised the definition as the law that provides for offences and punishment within the military environment. ${ }^{66}$ Even in our teaching of Military Law as a subject, ${ }^{67}$ we define military law as those rules of law that pertain to the maintenance of military discipline, which control soldiers in times of peace and war and which are in essence regarded as being the criminal law of the soldier. This relegates military law to the disciplines of criminal law and criminal procedure. ${ }^{68}$ This would suffice if the content of military law were understood as being limited only to the military justice system.

I would however argue that this traditional approach and understanding of what defines military law could no longer be regarded as a true reflection of contemporary military law. Our understanding of the various legal and other disciplines as well as external factors shaping the military environment domestically and globally should reshape our definition and understanding of military law.

Although military law could be included under the banner of both criminal law and criminal procedure, the authoritative relationship existing between the SANDF as an organ of the state and the individual soldier reflects aspects of administrative law. ${ }^{69}$ Administrative law is further relevant to administrative aspects such as boards of inquiry, redress of wrongs procedures and specific aspects of the

${ }^{66}$ A number of sources from 1897 to 1929 confirm military law as "the law relating to and administered by military courts, and concerns itself with the trial and punishment of offences committed by officers, soldiers and other persons, ... who are ... subjected, for the time being, to the same law as soldiers - see Morrison, CG Notes on Military Law, Organisation and Interior Economy (Harrison 1897) at 1 - and "the law which governs Officers and Soldiers in peace and war, at home and abroad ... it is the law relating to, and administered by, Military Courts, and is chiefly concerned with the trial and punishment of offences ... - see Banning, S.T. Military Law (Gale \& Polden 1929) at 1.

${ }^{67}$ Military Law forms part of the module Criminal and Military Law 144, presented at the Faculty of Military Science, Stellenbosch University as a first-year subject in the Human and Organisational Development programme, required as part of the BMil degree completed by members of the South African National Defence Force.

${ }^{68}$ See also the explanation in Morris, LJ Military Justice: A Guide to the Issues (Praeger 2010) at 1 .

${ }^{69}$ Van der Westhuizen, H 'An Introduction to the Military Courts in South Africa and Some Recommended Changes' (1994) 14 African Defence Review at 18; Nel op cit 24. 
Military Ombud. Other matters pertaining to the Military Ombud and military unions in turn overlap with labour law.

Changes brought about by the Constitution resulted in a number of constitutional challenges to the military justice system and raised human rights concerns. Even in situations where it is argued that the interests of the state are paramount and the needs of individual soldiers subservient to the needs of the SANDF, one cannot underestimate the effect and influence of human rights in this environment. ${ }^{70}$ The transformation of the military justice system in a human rights context remains an ongoing process, but unfortunately not one that seems to be powered from within the ranks of the military law practitioners. This is unfortunate, as one should never underestimate the potential influence of the military law practitioner in this developmental process. I will return to this aspect shortly.

There are also a number of aspects outside the domestic legal environment that should further influence and shape our understanding of military law. This may be overlooked in situations if military law is merely equated with military justice. The SANDF's international deployments with the United Nations and the African Union bring with them the inclusion of international humanitarian as well as international human rights law. This view is in fact a constitutional imperative in that the Constitution requires the SANDF to execute its mandate in accordance with "the principles of International Law regulating the use of force". 71

A further aspect that spans the international and domestic operational environment is the utilisation of the SANDF in a number of secondary roles. It is generally accepted that armed forces are utilised in eight clusters outside of their traditional utilisation, including support of the police services, border protection and support of socio-economic development. ${ }^{72}$ The most prominent role for the SANDF is arguably its utilisation in anti-piracy and anti-poaching operations. These types of operations, whether in international waters or on the borders of the Republic, is regarded as law-enforcement operations, thereby effectively excluding the International Humanitarian Law aspect. It brings the SANDF squarely into human

\footnotetext{
${ }^{70}$ See the discussion in this regard in Rowe, P The Impact of Human Rights Law on Armed Forces (Cambridge University Press 2006) at 5-9.

${ }^{71} \mathrm{~S} 200(2)$ of the Constitution.

${ }^{72}$ Vreÿ, F \& Nel, M 'Employing Armed Forces: The Rise of More Constructive and Ethical Secondary Roles' Politeia, (2009) 28 (3) at 23. See also SSR Backgrounder 'The Armed Forces: Roles and Responsibilities in Good Security Governance' (Geneva Centre for the Democratic Control of Armed Forces, 2015), available at https://www.files.ethz.ch/isn/195684/DCAF_BG_10_The\%20Armed\%20Forces.11.1 5-1.pdf.
} 
rights territory and law enforcement operations for which training may be severely limited.

These, coupled with the influence of various academic disciplines, are just a few examples showing that the historically accepted definition can no longer be regarded as adequate. Provision should be made for a wider application than criminal law and criminal procedure. To this end, the definition by Vashakmadze may be of assistance. ${ }^{73}$ Although the author's definition refers to the narrower concept of military justice as "a distinct legal system that applies to members of armed forces and, in some cases, civilians", ${ }^{74}$ it is submitted that it could be applied to the wider concept of military law as well. By applying the wider term of 'legal system' it allows for the acknowledgement of the various disciplines influencing military law, and the term 'distinct' acknowledges and retains the unique nature and environment within which the military operates.

Fidell's ${ }^{75}$ description of operational law could also successfully assist in defining the essence of contemporary military law, not only in times of war but also in times of peace. He describes operational law as

[T]hat body of domestic, foreign, and international law that impacts specifically upon the activities of ... forces in war and operations other than war ... It is a collection of diverse legal and military skills, focussed on military operations. It includes military justice, administrative and civil law, legal assistance, claims, procurement law, national security law, fiscal law, and international law.

It is not only our definition of military law that needs to expand; our understanding of the concept itself and the parts comprising it also need to expand. This understanding not only comes from a theoretical military legal scholarship perspective, as discussed above, but also from an operational perspective of the military legal practitioner, whose role is pivotal in the development of Military Law. The practitioner's role should not be underestimated.

\section{The military legal practitioner}

The military is a unique environment where a society has unique expectations of its soldiers and where "discipline, organisation and hierarchy play a

\footnotetext{
${ }^{73}$ Vashakmadze op cit.

${ }^{74}$ Ibid 10.

${ }^{75}$ Fidell, ER 'Military Law' (2011) 140 (3) Daedalus, the Journal of the American Academy of Arts \& Sciences at 171 quoting the Judge Advocate General's School of Army Operational Law Handbook.
} 
crucial role". ${ }^{76}$ It is in other words an organisational society with a distinctive culture. ${ }^{77}$ As such, the lawyers that operate within this environment must be part of and understand this organisational culture. The nature of contemporary military actions and operations is such that there is little that does not require some form of legal advice. ${ }^{78}$ The nature of the legal services provided includes, apart from military justice aspects, the writing of directives and policies, legal advice, training of soldiers on aspects of the law of armed conflict as well as ad hoc advice to commanders during military deployments. ${ }^{79}$

Luban $^{80}$ identifies legal advice as the most important of these services regarding its influence on the development of the law. He argues that, in spite of popular opinion, judicial decisions are not the main driver for legal development. This is especially true in the operational environment where litigation is the exception rather than the rule. Courts will therefore not have the regular opportunity to apply the law - it is rather the day-to-day interaction and advice given to commanders by military law practitioners that shape the way in which the law is applied, ${ }^{81}$ thereby potentially developing the law.

To this end, the need and importance of ethical and knowledgeable advice cannot be emphasised enough. There is an ethical obligation on the military lawyer to give independent and frank advice to commanders. He or she must give his best interpretation of the law, even if the client is not receptive to the advice. It could be very dangerous in the military, and more specifically the operational environment, merely to tell the client what he or she wants to hear when he or she pushes the boundaries of legality. ${ }^{82}$ Considering the number of roles fulfilled by the armed

${ }^{76}$ Vashakmadze op cit 10. The need for a separate system was confirmed in Minister of Defence v Potsane; Legal Soldier (Pty) Ltd and Others v Minister of Defence 2002 (1) SA 1 (CC) para 31.

${ }^{77}$ The traditional uniformity of military culture has made the regulation of soldiers easier in the sense that the influence of different cultures on the law has not played any significant role in the development of military law. However, the advent of the Constitution may necessitate the investigation of the influence and role of cultural diversity in the future of military law. The issues of gender and feminism are also playing a larger role in military sociological research, potentially impacting the legal environment. See Cotterrell, R 'Law in Culture' (2004) 17 (1) Ratio Juris for a discussion on the influence of culture on law.

${ }^{78}$ See also Fidell 'Military Law' op cit 165.

${ }^{79}$ Luban op cit 318.

${ }^{80}$ Ibid 319.

${ }^{81}$ Ibid.

${ }^{82}$ See in this regard Luban op cit 319-20, where he discusses the infamous 'torture memos' where military lawyers bent the law between 2002 and 2005 to allow the use of harsh interrogation techniques - a more palatable way of referring to torture. Their 
forces and the resultant advice required, this is no easy task. Commanders are frequently faced with a number of ethical and legal challenges on which military legal practitioners must advise. On the one hand, the military legal practitioner is faced with political directives and agendas, and on the other hand, he or she is confined by the applicable (and often less permissive) legal rules. This situation is exacerbated by the fact that military law includes a number of different disciplines.

Whetham ${ }^{83}$ explains that, although the law provides the framework and the context within which commanders must make their decisions, it if not sufficient for providing the required answers. Nor is it sufficient merely to determine the legality of a particular action. One is required to make a judgement on whether the actions are also legitimate. Decisions must therefore not only be lawful; they must also be ethical. The military legal adviser must consequently give ethical legal advice to protect the integrity of the law. ${ }^{84}$ In an environment where society expects soldiers to lay down their lives, the integrity of the legal system is critical for the enforcement of its rules. Discipline is critical for an effective military force, ${ }^{85}$ whether one expects soldiers' discipline in terms of military justice or their discipline in executing any of their other functions. It has been argued that the effectiveness of the military justice system in its ability to enforce discipline is to a large extent dependent on the perceived fairness of that system. ${ }^{86}$

This argument once again underpins the importance of the role of the military legal practitioner. The Commander is not the legal expert, nor is he or she necessarily aware of legal developments and constitutional concerns relating to the execution of his or her tasks. This is the domain of the legal adviser, and herein lies the danger. It is imperative that the legal adviser keep abreast of developments within their specialised area of law. There are a number of ways in which this can be done, such as studying recent research, attaining further academic qualifications in their chosen area, or attending skills development and subject-specific courses and seminars. This raises the question regarding the extent to which this is being pursued.

reasoning prevented the prosecution of 101 cases of waterboarding, sleep deprivation and assaults.

${ }^{83}$ Whetham, D 'Ethics, Law and Conflict' in D Whetham (ed) Ethics, Law and Military Operations (Palgrave Macmillan 2011) at 10-2.

${ }^{84}$ Luban op cit 320.

${ }^{85}$ Morris op cit 3, Smart, D 'The Revision of South African Defence Legislation: A Personal View' African Defence Review (1994) at 30 and Renaut, C 'The Impact of Military Disciplinary Sanctions on Compliance with International Humanitarian Law' (2008) 90 (870) International Review of the Red Cross at 320.

${ }^{86}$ Heinecken, L et al 'Military Discipline: Where are We Going Wrong?' (2003) 25 Strategic Review for Southern Africa at 89. 
Certain areas in military law lend themselves more readily to selfdevelopment. Those legal practitioners operating in the international law environment will invariably be compelled to become conversant in the latest developments, conventions and treaties. The challenge here lies in the breadth of this area of law and South Africa's involvement in a number of conflict domains. Military legal practitioners must become experts in the land, air, maritime and cyberwarfare domains, running the risk of becoming a 'Jack of all trades but master of none'. Expertise requires time and in-depth knowledge.

The legal practitioner within the military justice environment specifically faces a serious challenge. It has been my experience that some military legal practitioners do not feel the need to expand their knowledge much further than that obtained during their graduate studies. In a discussion on the importance of further education and research, it was stated by a prosecutor that those of us involved in education and training are not busy with 'real' law. 'Real' law happens in the courts. ${ }^{87}$ It is however my contention that 'real' law is not only applied in the courts. The legal practitioner, in his or her day-to-day role as adviser to the Commander, plays a much more effective role in the development of the law. However, even if the military law practitioner involved with military justice did feel inclined to broaden his or her knowledge of military justice he or she is faced with the reality that his or her area of law has remained stagnant for a number of years.

\section{Conclusion}

The complex nature of the contemporary military environment in which military officers must operate and on which the legal practitioner must be able to advise, is aptly reflected by Whetham ${ }^{88}$ in discussing professional military education as -

[A]n advanced appreciation of history as well as [an analytical engagement] with issues of contemporary and future defence and international security, from political, economic and international relations theory, through to strategy, security structures and equipment procurement policies. Invariably

\footnotetext{
${ }^{87}$ This is an opinion that is not unique to the military law environment. For a discussion on the opinion that judges and practitioners feel that academics do not address their practical needs, see McClintock MD 'The Declining Use of Legal Scholarship by Courts: An Empirical Study (1998) 51 Oklahoma Law Review at 659-95. See also Heinecken op cit at 42, where she argues that the SANDF in general "lack [an] understanding and appreciation of academic research. The SANDF rarely solicits research even where there is a dire need for it".

${ }^{88}$ Whetham, D 'Introduction: Purpose, Content and Structure' in Whetham op cit 2.
} 
... [this] ... will include a legal dimension and, due to the way it impacts on every area of the military profession, increasingly it is becoming recognized that the ethical dimension also needs to be addressed as an explicit subject alongside the legal studies.

This reiterates the need of the military legal practitioners to expand their knowledge base outside the law, drawing knowledge from other disciplines to inform and expand their own legal discourse. It is accepted that interdisciplinary work has "reshaped the legal landscape" ${ }^{89}$ Understanding the law requires one to understand the social practices of its legal community - in the context of this article, the military legal community. It is argued that an understanding of the social practices requires knowledge and understanding of the "general culture of the society in which the legal community is embedded". .0

The importance of the military legal practitioner being involved in research - whether as practitioner or scholar - cannot be emphasised enough. The difficult environment within which they must operate can be described as "being complex, demanding, chaotic, challenging, irregular, unpredictable and uncertain" with the application of the law being "equally challenging and demanding ... uncertain and unpredictable". ${ }^{91}$ Members of the military will necessarily approach matters from a different perspective than civilians. ${ }^{92}$ This does not mean that the military alone owns military law. ${ }^{93}$ There are a number of role players involved in day-to-day military conduct ${ }^{94}$ and this is exactly why collaboration with research disciplines outside the legal environment becomes necessary in order to understand the influences of the different disciplines better. ${ }^{95}$ It has been argued that understanding the law means more than merely reading legislation and court decisions. To be properly understood, law must be placed in "a broad historical, socio-economic, psychological and ideological context". ${ }^{96}$ Although the military justice system

\footnotetext{
${ }^{89}$ Rhode op cit 1338 . McClintock op cit also discusses the importance of interdisciplinary work.

${ }^{90}$ Van Hoecke \& Warrington op cit 497.

${ }^{91}$ McEvoy, P 'Law at the Operational Level' in Whetham op cit 110-1.

${ }^{92}$ Luban op cit 336 . He argues, "people who see the world differently are likely to see the law differently as well".

${ }^{93}$ See also Fidell 'Military Law' op cit 171, who argues that the military should not have "a monopoly in learning in the field of military justice" in a democratic society.

${ }^{94}$ Luban op cit 338 refers to politicians and the media. One can also include the emergence of private military companies, non-governmental organisations, transnational organisations, civilian industry and of course the civilian population impacted by these decisions, to name a few.

${ }^{95}$ See also Rhode op cit 1329.

${ }^{96}$ Van Hoecke \& Warrington op cit 496.
} 
should not be isolated from the civilian justice system, ${ }^{97}$ the unique nature of the military would argue against a complete 'civilianisation' of military law, something that may happen if military law practitioners do not stand up and own their subject.

${ }^{97}$ Vashakmadze op cit 21. 